\title{
¿Lucidez o fantasía neurótica? Gustave Doré como ilustrador de la Divina Comedia: el caso del bosque de los suicidas
}

\author{
David Villalta Jiménez \\ Universitat Auntònoma de Barcelona \\ David.Villalta@e-campus.uab.cat
}

\section{Resumen}

En este artículo se examina la visión con que Gustave Doré (I832-I883) dio forma al bosque de los suicidas en sus ilustraciones para la Divina Comedia de Dante Alighieri en I86I, partiendo de la recepción de la crítica así como de una comparativa entre el texto original y las distintas obras que han ilustrado el canto a lo largo de los siglos. El objetivo es dilucidar hasta qué punto la crítica contemporánea del artista acertó en su visión peyorativa del tema planteado y, al mismo tiempo, ubicar y definir la visión romántica del canto. Las fuentes y los datos aquí tratados descubren cómo Doré, lejos de lo prejuzgado, abordó la ilustración de la Comedia con un planteamiento innecesariamente correcto o incorrecto, sino hijo de su época, de su sensibilidad y con diversas conexiones, ineludibles, con el pensamiento estético del momento.

Palabras clave: Gustave Doré; Dante Alighieri; Divina Comedia; Canto XIII; Pier della Vigna; Romanticismo; ilustración.

\begin{abstract}
The present article seeks to dig into Gustave Dorés (I832-1883) vision of the Wood of the Suicides from his illustrations of the Divine Comedy (d. I86I), establishing a comparison between its critical reception, the works that have illustrated the chant over the centuries and Dorés works themselves. A goal here is to glimpse if negative criticism had any basis beyond the prejudices of that period and, at the same time, to showcase the Romantic vision that transformed the chant into something completely new in the XIXth century. The sources prove how Doré, far from what critics intended to see in his works, approached Dante Alighieri's capolavoro with a neither correct or incorrect vision, but a vision that is a part of his own time and sensitivity, with several inescapable connections with his contemporary aesthetic views and theories.
\end{abstract}

Keywords: Gustave Doré; Dante Alighieri; Divine Comedy; Canto XIII; Pier della Vigna; Romanticism; illustration. 


\section{LA CRÍTICA. ENTRE CONTRADICCIONES Y CONFLICTOS}

Mit einer fast nervösen, fieberheissen Phantasie begabt, setzte er das vielleicht nur flüchtig Gelesene in Bilder um, welche manchen sensationellen Zug nur ihm, nicht Dante verdanken, und nicht immer konnte er dem Anreiz widerstehen, aus Dante's strenger Dichtung ein phantastisches Zaubermärchen zu machen, wie im dreizehnten Gesang der Hölle, wo er die in Bäume verwandelten Sünder als Baumstämme mit menschlichen Gesichtern und Formen darstellt, eine Auffassung, welche Dante's Worten schlecterdings widerstreitet (Volkmann I897: I39). ${ }^{\text {I }}$

$\mathrm{C}$ on estas palabras describía Ludwig Volkmann, en su célebre Iconografia Dantesca, la manera con que Gustave Doré representó en sus célebres grabados el bosque de los suicidas (figs. I, 2 y 3), el turbador escenario que cruzan Dante y Virgilio en su paso por el séptimo círculo del Infierno y que tanta literatura generaría por su carácter dramático, su hábil exposición del contrappasso y la idea que subyace en su concepción, recuperando la imagen del Polidoro virgiliano y al mismo tiempo actualizándola bajo la óptica del hombre medieval y la consideración contemporánea del suicidio. ${ }^{2}$ En su análisis iconográfico, el alemán incidió en algo que tantos otros críticos de la obra de Doré se han afanado en remarcar: la falta de fidelidad, la tendencia a la «invención» de un Doré que se llega a poner incluso por encima del poeta. Como se llegó a afirmar en la crítica francesa, «Más que Dante ilustrado por Doré, [su Infierno] parece Doré ilustrado por Dante» (Larchey I869: 202), lo cual puede ayudar a hacerse una idea de la evidente falta de consenso a la hora de valorar el trabajo del alsaciano y el recelo con que fue recibido allende el entusiasmo popular.

Si bien actualmente la fama universal de Doré parece haberlo elevado a la categoría de los más ilustres artistas de su tiempo, apreciado por el conocimiento popular y académico como uno de los mejores ilustradores del siglo XIX y especialmente acertado a la hora de recrear las penurias de la Londres victoriana y los mundos oscuros del folclore y la literatura, sus grabados para la Divina Comedia no dejaron de sufrir los embates de parte de la crítica

I. «[Doré] Dotado de una fantasía casi neurótica, febril, traducía en dibujos cosas que quizá no había leído más que por encima, y que por esto le deben ciertos tratos sensacionales a él, no a Dante, y no siempre supo resistirse a la tentación de hacer de la Divina Comedia un cuento mágico y fantástico, como en el decimotercer canto del Infierno, donde representa a los pecadores convertidos en árboles, como troncos con rostro y miembros humanos, un concepto que contrasta mucho con el de Dante.»

2. Deben tenerse en cuenta los matices en el empleo del recurso que ponen de relieve la voluntad de Dante de adaptar esa imagen clásica a su percepción contemporánea del suicida. Por lo tanto, si bien tanto Polidoro como los suicidas del canto XIII se presentan al lector bajo la forma de un árbol, cabe señalar que mientras la nueva forma del hijo de Príamo surge de su mismo cadáver, los árboles del decimotercer canto lo hacen a partir de las almas de los condenados a modo de semilla (Arqués 1998: 86-87). 
nacional (en especial la más cercana a la Academia, aun con excepciones), así como de la extranjera, por parte de los círculos más conservadores respecto a la figura del Poeta, como pueden ser Alberto Rondani en Italia (Sgarbi 2003: 69-72) o el mismo Volkmann en el contexto germano quien, en una suerte de curioso aviso, recomienda al observador no dejarse llevar por la fama de sus ilustraciones y examinarlas con ojo crítico para no caer en valoraciones superficiales ("Dies Alles muss man sich gegenwärtig halten, wenn man an das Werk des grossen französischen Illustrators herantritt»). ${ }^{3}$ Esta advertencia, sin duda, pone en evidencia la desaprobación con que los estudiosos del dantismo observaban no solo la propuesta doréniana sino también, y en consecuencia, su calado popular.

Que Doré fue un artista incomprendido es un hecho ampliamente demostrado y de sobras conocido. Ya en el prefacio de su biografía, su amigo Blanchard Jerrold (I826-1884) manifiesta cómo el antaño Doré joven, impulsivo e ilusionado acabó cediendo el testigo a un genio alicaído y resignado ante la falta de reciprocidad de sus compatriotas (Blanchard Jerrold I892: iv). El mismo artista se lamentaba, incluso, de su moderado éxito como pintor, llegando a decir que debía «matar» al ilustrador para poder ser reconocido como un maestro de los pinceles (Blanchard Jerrold I892: IO2). A día de hoy tampoco puede decirse que el francés se haya quitado el peso de la fama popular, entendida en su sentido más moderno, algo que se evidencia en la ausencia de un corpus teórico y crítico, a lo que se ha apuntado desde algunos sectores de la disciplina histórico-artística favorables a una puesta al día de la valoración de sus obras (Cole 1994: 95-I06). Por supuesto, no puede catalogarse a Doré con facilidad y quizá esto haya sido el origen de cierto ostracismo científico; no casó con los preceptos académicos más conservadores de su época ni con las tendencias rompedoras con la tradición. Esto acabaría comportándole una dura condena y, según su propio testimonio, una frustración irresoluta. De todos modos, no debe darse a entender que toda responsabilidad fue suya, pues en lo que respecta a su tarea de ilustrador y a las imágenes del Poema, el discurso de la crítica ha incidido en demasía en comparaciones basadas en una lectura literal del texto (Cole 1994: 95).

Las palabras de Volkmann están en consonancia con las de otros como Rondani, y en esencia apuntan a que el francés a duras penas había comprendido la Comedia; que su lectura, de corrido y superficial, no había sido lo suficientemente profunda como para comprender mejor algunas de las escenas que luego representaría. Está presente la idea de que determinadas lecturas son incorrectas, si bien no parece especificarse cuáles son las más ortodoxas. Verdad o no, puesto que difícilmente se puede llegar a dilucidar con exactitud el

3. «Todo esto debe ser tenido en cuenta cuando uno se acerca a observar el trabajo del gran ilustrador francés» (Volkmann, 1897: 139). 
grado de atención que Doré puso en su lectura del poema ${ }^{4}$ el ejemplo que nos brinda Volkmann para evidenciar esa inventiva y esa "neurosis», entendidas con una connotación negativa, es controvertido.

El de Leipzig identifica en la representación del bosque de los suicidas esa falta de coherencia, sintomática de la desbordante imaginación de su autor. Cierto es, como él mismo afirma y como se analizará más adelante, que el bosque descrito por Dante se caracteriza por ciertos aspectos que lo alejan, aparentemente, de aquel ilustrado por Doré. Sin embargo, en otros guardan diversas similitudes. Doré inventa, efectivamente, pero por otro lado en sus invenciones logra recrear la atmósfera opresiva, enfermiza, tenebrosa y de desasosiego del bosque que el lector descubre en la Comedia. En este sentido no debería ser un atrevimiento afirmar que su representación del canto XIII es de las más acertadas que haya visto la historia del arte hasta la fecha, más aun pudiéndose percibir su influencia no solo en trabajos ligeramente posteriores (D’Argent, Buttura) sino también en artistas de los siglos XX y XXI de alrededor del mundo (Henry Otto, Kentaro Miura, Wayne Barlowe y multitud de artistas independientes de la era Internet), algo que pone de manifiesto que esa misma lectura «imaginativa» de los versos no fue flor de un día sino que coincidió y sigue coincidiendo con una sensibilidad enraizada en el paradigma estético del romanticismo decimonónico.

Teniendo esto en cuenta, el presente artículo parte de esa afirmación en concreto, aunque sin dejar de lado el resto de valoraciones que pusieron en cuestión el acierto de las escenas plasmadas en los grabados. La intención no es otra que vislumbrar si, verdaderamente, la acusación de falta de comprensión por parte de cierto sector crítico tiene razón de ser más allá de la superflua literalidad de los versos del poema. Y del mismo modo en que se aludirá constantemente a las valoraciones negativas, es imprescindible hacer mención y tener en cuenta la convicción que parte de los valedores de Doré defendieron con entusiasmo, y que giró alrededor de la idea de que artista y poeta estaban conectados. 5 Por un lado, se abordará el trato del escenario (aspecto en que Doré, ciertamente, destacó por encima de sus predecesores y también sus

4. Sí se tiene constancia, sin embargo, de que creció escuchando la narración de obras clásicas de boca de su abuela (Renonciat I983: I4) y que, ciertamente, no abordó los grabados sin haber prestado atención al texto (Blanchard Jerrold I892: IIO), algo que su propio hermano, Émile, ratificaría al contar que Gustave estuvo trabajando en la Comedia desde I855 (Carlier 2004: 31).

5. Idea que imagino propia de la época, y que curiosamente, en el contexto del arte y el dantismo, se repite en el caso de Francesco Scaramuzza (I803-1886). El también ilustrador de la Comedia explicó en diversas ocasiones cómo contactaba con los espíritus de los grandes literatos de su patria (Ariosto, Goldoni, el mismo Dante). De hecho, bautizaría su obra maestra con el título Poema sacro dettato dallo spirito di Lodovico Ariosto al medio Francesco Scaramuzza (1873), resaltando su supuesta capacidad de comunicación con los difuntos. 
contemporáneos $)^{6}$ y por otro se analizará la representación y visión doréniana tanto de los suicidas como del protagonista del canto XIII, Pier della Vigna.

\section{VISIONES HERMANADAS: LA GEOGRAFÍA DANTIANA y la construcción de la SelVa de Doré}

Como ha hecho y hará a lo largo del poema, especialmente en Infierno y Purgatorio, Dante construye unos escenarios que en ocasiones llegan a ser protagonistas y que en absoluto pueden tildarse de inofensivos. En su descenso junto a Virgilio, el poeta no lucha únicamente contra abominaciones infernales sino también contra riscos escarpados, caídas ciegas y abismos insalvables; ahí, Doré se mostró acertado ${ }^{7}$ y, es más, sentó precedentes a la hora de representar el infierno dantesco, de convertir su geografía en un enemigo u obstáculo más a tener en cuenta. En este caso, Dante describe el bosque delimitando el espacio con precisión, dejando apenas cabos sueltos que den lugar a interpretaciones dispares: léase como se lea, es evidente que el toscano imagina un lugar muerto a simple vista. En la introducción de este escenario (If., XIII, 4-6), el poeta niega cualquier signo positivo (non...) para luego reemplazarlo por un antónimo de evidente connotación negativa (ma...) (Urraro 2007: 3); teniendo esto presente, no puede decirse que el lápiz del francés diese a luz un paisaje que acusase una grave falta de verosimilitud:

Non fronda verde, ma di color fosco; non rami schietti, ma nodosi e 'nvolti; non pomi v'eran, ma stecchi con tòsco. (If. XIII, 4-6)

No se trata, desde luego, de un entorno apacible ni de deslumbrante verdor; el bosque al que entran los poetas es oscuro, venenoso, amenazante. Propio, debería recordarse, de aquellos bosques tenebrosos que el Romanticismo literario

6. Gustave Doré convirtió los escenarios de su Infierno y Purgatorio en un elemento más que, en ocasiones, se sirve de sí mismo para traducir algunos de los pasajes de la Comedia. No son pocas las veces en que las figuras de Dante y Virgilio son reducidas al mínimo, con el aparente objetivo de evidenciar no solo las colosales dimensiones del entorno (que bien procura señalar el poeta cuando el momento lo exige) sino también la fragilidad y la menudez de los protagonistas en un escenario hostil e inabarcable que evoca con cierta claridad a la idea de lo sublime. A diferencia de los riscos, los abismos y el resto de paisajes que se advierten como un enemigo más en la travesía doréniana de los poetas, la gran mayoría de artistas que ilustraron el poema trataron el escenario como un fondo más, con escasa implicación en la narrativa visual como puede apreciarse en Della Quercia, Stradano o Flaxman.

7. Es interesante, al mismo tiempo, advertir cómo Doré tradujo el carácter de cada una de las partes en los escenarios. El ejemplo más llamativo quizá sea el del Purgatorio, donde juega con paisajes ásperos y amenazantes (el ascenso por las montañas del canto IV, vv. 3I-32) con otros de aspecto bucólico, de naturaleza exuberante (el encuentro con Pia de' Tolomei, V, vv. 130-136), ilustrando el carácter intermedio del lugar, a caballo entre la oscuridad y la luz, el desconsuelo y el consuelo, el castigo y el resguardo, Lucifer y Dios. 
reviviría con acierto $^{8}$ (si bien, tradicionalmente, siempre han gozado de un significado profundo que el folclore se ha encargado de atestiguar, [Bettelheim 1977: II5]) y que Doré, dada su cercanía al mundo de las letras, debió de tener presentes de manera constante, más allá de su temprana afición a recorrer lápiz en mano los bosques del Monte de Santa Odilia, donde incluso llegó a perderse en una ocasión (Blanchard Jerrold I892: I3-I4). Del mismo modo, tampoco deben olvidarse trabajos inmediatamente anteriores a su Infierno como fueron las ilustraciones para Viaje a los Pirineos o El judio errante, donde se gestaría un modelo de bosque al que recurrió continuamente tanto para sus imágenes del poema como para otras de posteriores como las pertenecientes a su Don Quijote o el Orlando furioso (fig. 4). Esta similitud, desde luego, puede reforzar la crítica de Volkmann y pone de manifiesto cierto carácter de «intercambiabilidad» de los elementos que conforman las propuestas del artista para su serie de grandes obras de la literatura ilustradas. La impresión de una suerte de «universo doréniano» puede poner en tela de juicio la singularidad, la fidelidad y la adecuación de su visión del poema; por supuesto, es fácil e incluso comprensible caer en la desconsideración de una resolución aparentemente genérica. Sin embargo, no parece ser que la crítica vaya en esa dirección.

En representaciones anteriores, la mayoría de artistas abordaron el canto con un planteamiento conservador. En el siglo XV, Priamo della Quercia sería fiel a la descripción en sus miniaturas (fig. 5), con un bosque marchito y unos condenados convertidos en unos troncos oscuros y secos. No se puede decir lo mismo del contemporáneo anónimo que representó los árboles cargados de hojas verdes (fig. 6), que poca relación guardan con aquellos de «ramas nudosas» que imaginase el Dante, pero bien puede considerarse una curiosa excepción, quizá deudora de la visión de Botticelli (fig. 7). En realidad, de todas las anteriores representaciones del bosque de los suicidas llevadas a cabo entre el vastísimo periodo entre el siglo XIV y fines del XVIII, la mayoría apenas distan en exceso de las de Doré, por lo menos en la representación del paisaje. De entre las más conocidas, las de Stradano (fig. 8), della Quercia o Britto (fig. 9) coinciden nuevamente en un escenario seco, duro, árido; en resumen, literalmente fiel a los versos.

8. El bosque romántico se convierte en un espacio aislado donde convergen las sombras, el misterio y, desde luego, el impulso primitivo de un hombre que empieza ya entonces a ser devorado por la ciudad moderna e industrial. Desde los bosques (hasta setenta menciones a este tipo de lugar) que devoran el castillo del barón en Los elixires del Diablo (I8I5) hasta la amenaza invisible de antiquísimas entidades en los bosques de Gales en El gran dios Pan (I890) o La novela del sello negro (I895) de Arthur Machen, pasando por aquellos que con sus cacerías pervierte el San Julián de arrebatos psicóticos de Flaubert (La leyenda de San Julián el Hospitalario, 1875), las localizaciones boscosas o selváticas (o, dicho de otro modo, la Naturaleza desbordada) se convierten en sinónimo de algo arcano, oscuro, amenazante, ruinoso, y aun así lo suficientemente poderoso como para ejercer una potente atracción sobre el destino de los personajes. 
¿Qué pudo motivar, por lo tanto, el comentario de Volkmann? Dadas las similitudes del paisaje respecto a las ilustraciones anteriores, es de imaginar que sus críticas iban dirigidas a la representación de los suicidas más que al entorno o a su interacción con los viajeros. La manera en que los condenados se muestran en los grabados de I86I, desde luego, supone un paso hacia delante (si esto se entiende como el abandono de ciertas formas o recursos comunes, sin connotaciones positivas ni negativas de ningún tipo), una rotura con la tradición representativa de la Comedia y la ratificación de las tímidas novedades introducidas en los albores del Romanticismo por mano de artistas del calado de John Flaxman o William Blake, quienes ya intuyeron la figura humana en esos árboles. Cuando el poeta alcanza el lugar y comienza a percibir su naturaleza, expresa que:

Io sentia d'ogne parte trarre guai, e non vedea persona che 'l facesse; per ch'io tutto smarrito m'arrestai.

Cred'io ch'ei credette ch'io credesse che tante voci uscisser, tra quei bronchi da gente che per noi si nascondesse.

(If. XIII, 22-27)

Sorprendido, Dante se detiene junto a Virgilio al oír los lamentos que proceden de algún lugar del bosque, incapaz de identificar su origen. La imagen, por supuesto, resulta de lo más desasosegante: un entorno amenazador donde lloros y gritos de todo tipo surgen de la nada, entremezclándose y dando lugar a una macabra sinfonía. ${ }^{9}$ Para el poeta, dar un paso adelante deviene una gravosa tarea. Merece la pena recordar que a esas alturas del viaje Dante se ha topado con todo tipo de monstruosidades (el minotauro, los demonios de las murallas de Dite, Cerbero, etcétera); sin embargo su congoja no es menor ante la confusión que le provoca algo a priori inidentificable ${ }^{\mathrm{IO}}$. Esta especie de presencia por ausencia vertebra los primeros compases del canto, residiendo

9. A propósito de esto y de cara a las posteriores reflexiones acerca de Pier della Vigna conviene citar a Urraro, quien señala la expresividad fónica de las palabras empleadas por Dante a la hora de introducir este escenario. Textualmente: «Y este inicio del encuentro de Dante con un suicida se efectúa, poéticamente, a través de un lenguaje de grandísima eficacia semántica y fónica. Palabras como schiante, scerpi, sterpi, serpi, de las cuales las últimas tres permanecen entre ellas, son signos que, en su expresividad fonemática, remarcan el sentido del dolor y de la angustia mostradas por el personaje que es aún desconocido para Dante.»

IO. Por lo que respecta a las distintas criaturas que pueblan el Infierno, es interesante y conviene tener presente la acertada clasificación de lo monstruoso y lo grotesco elaborada por Lascault y desarrollada más adelante por García Cortés. En este caso, los suicidas pertenecerían a la categoría de lo grotesco por confusión de géneros, así como el Minotauro. Completan el espectro lo grotesco por transformación física (los gigantes del noveno círculo), lo grotesco por supresión o desplazamiento de los órganos del cuerpo (Mahoma, Bertran de Born), lo grotesco por la composición de nuevos seres de elementos humanos y animales (los centauros y las arpías) y, por último, lo grotesco por metamorfosis (Agnello) (García Cortés 1997: 22-24). 
en ella la sorpresa, el impacto que supone conocer más adelante la suerte de los ahí condenados, la imagen de Dante quebrando la ramita sangrante del cuerpo de Pier della Vigna. Las conexiones entre la Comedia y la narrativa gótica, precisamente se manifiestan en semejante recurso, comparable a la introducción de Gerión al final del canto XVI (II5-I36), y permite intuir la gestión de la tensión y el misterio que en el siglo XIX se daría en el incipiente género del terror.

Doré, en efecto, rompe con ese misterio. Para Doré, es más, parece que nada de ese efecto sorpresa es importante en su visión del canto. Y es ahí donde, probablemente, apuntasen los más críticos; ya no solo al canto XIII en concreto, sino también a todas las libertades que el francés se tomó a la hora de trasladar los versos a la imagen, puesto que lo mismo hace a continuación con el hijo de Crisaor. ${ }^{\text {II }}$ Aun así, merece la pena remarcar cómo la crítica no fue tan dura con las libertades de otros ilustradores como Francesco Scaramuzza, quien a pesar de su conexión espiritual y sentimental con el poema también se permitió ciertas licencias, inadvertidas en los comentarios dedicados a su magnum opus.

En las ilustraciones de Doré, los condenados aparecen como árboles con formas humanas, en posturas expresivas de todo tipo que respiran dolor, sufrimiento y arrepentimiento. Impacta la imagen de un suicida con la cabeza apoyada en sus brazos, otros echándose las manos a la cabeza en una actitud desconsolada, lamentando la situación en que se encuentran. No son más que personajes anónimos, fruto de la imaginación del artista, y aun así sintetizan con un solo gesto la atmósfera doliente y arrebatadora que Dante plasmó con la única ayuda de sus versos. Es ahí donde brilla el trabajo de Doré. Ciertamente, en el bosque de la Comedia no hay formas antropomorfas. Sin embargo, sí está presente un pathos al que Dante logra dar forma con sus palabras, capaces de esbozar en la mente del lector el más acongojante de los escenarios. Por supuesto, con una lectura únicamente literal, resulta imposible trasladar esta imagen al papel. Se roza así una cuestión de vital importancia, aunque no para este artículo: ¿Cuál debe ser el papel del ilustrador? ¿Debe trasponer el texto literal a la imagen, o quizá plasmar su propia visión, fruto de su única y peculiar lectura? No parece que el dantismo decimonónico se incline hacia esto último. Rondani, en la línea del discurso exultantemente patriótico de su época, da una respuesta al dilema en nombre de quienes rechazan la visión del francés considerando que Scaramuzza logró recrear de manera fidedigna el contexto histórico de Dante: «Francesco Scaramuzza [...] ha sido más filosófi-

II. En este caso Doré opta por mostrar a Gerión desde un plano picado. En cierto modo, también juega con la aparición del ser. Tanto Dante como Virgilio no parecen percatarse de su presencia, de manera que su particular puesta en escena no deja de asemejarse a una reinterpretación del relato dantesco pero desde la perspectiva del antiguo rey de Tartessos. 
co que Doré. ¿Acaso os han transportado las escenas de Doré al Medievo, a sus creencias? Nosotros los italianos conocemos y amamos demasiado a nuestro Dante como para que otros vengan a cambiárnoslo sin que nos demos cuenta ni nos afecte.» Entran en conflicto, pues, dos visiones enfrentadas de la obra: la Comedia como un bloque medieval impermeable que debe ser entendido únicamente como parte de su época o la Comedia como clásico atemporal capaz de generar novísimas y peculiares lecturas.

\section{La redención de Pier della Vigna. El encaje CON EL MODELO ROMÁNTICO}

Si bien el francés aportó una visión singular del canto decimotercero, no por ello fue estrictamente inédita. Ya en 1793 (casi setenta años antes de la publicación del Infierno de Doré) John Flaxman confeccionaría sus propias ilustraciones de la Comedia, en cuya visión del bosque se intuyen unas discretas siluetas antropomorfas en perfecta sintonía con el carácter etéreo de su propuesta (fig. Io). Cerca de tres décadas después, William Blake visionaría un bosque de árboles también con rasgos antropomorfos (fig. II). Es más, y aunque no deba entenderse como un precedente, conviene recordar el fresco que Nardo di Cione realizó en la capilla Strozzi en Santa Maria Novella, donde recrea el bosque con siluetas humanas ${ }^{12}$ (fig. I2). Resulta obvio que la fórmula anticipada por el británico supuso una notable rotura con la anterior tradición representativa del bosque, adscribiéndose a una visión del suicida que mucho dista de aquella medieval, en que se consideraba un ser abominable (si bien se percibe en Dante una cierta empatía que pone en entredicho cualquier categorización tajante) a quien osa arrebatarse la vida con sus propias manos. Que se aprecie esta nueva deriva en el arte no es ni mucho menos casual. El Romanticismo humanizó al suicida y lo convirtió en sujeto y héroe; ya no se trataba del cobarde traidor a la voluntad divina, sino del valiente que desafía a las reglas y que, víctima de una pasión arrebatadora, concluye que ante el sinsentido de su vida lo mejor es abandonarla. El Werther ya sentó las bases en I774, convirtiéndose la obra de Goethe, como es sabido, en todo un éxito que

I2. Es difícil establecer una relación entre los bosques antropomorfos de Di Cione y Flaxman más allá de las meras suposiciones. Sí se tiene constancia de un viaje por Italia (Florencia, Milán y Roma) y de una larga estancia en la Ciudad Eterna que se extendería desde 1787 a I794 (Irwin I959: 212), donde llevaría a cabo sus ilustraciones de la Ilíada y la Odisea. No sería descabellada, por lo tanto, la idea de que en una visita a la ciudad del Arno contemplase el infierno de Di Cione en Santa Maria Novella, sirviéndole de inspiración para sus posteriores representaciones de la Comedia. Lo cierto, sin embargo, es que los dos tratamientos de los suicidas guardan una cierta similitud (el perfil en dos dimensiones, la ausencia de rasgos distintivos, la apariencia etérea, etcétera) como para no poder considerar una suerte de nexo entre ambos. 
llegó a motivar a algunos lectores a seguir los pasos de su protagonista ${ }^{13}$. Más adelante, Hoffmann recurriría al suicidio en algunas de sus obras para detener abruptamente el ascenso a la locura de sus personajes, quienes en sus últimos momentos de lucidez verían en el suicidio la única vía de escape ${ }^{\mathrm{I} 4}$. Imposible es, también en el mundo de las letras, olvidar a ese Quasimodo que muere de voluntaria inanición ante la tumba de su amada. Tampoco aquella reflexión incluida en el Zibaldone con que Leopardi expone los litigios internos de quien decide quitarse la vida (Leopardi I898: I092-93) y que tanto sentido cobran (y debieron cobrar) relacionadas con personajes de otras épocas en las lecturas decimonónicas del Poema. En pintura, se hace imposible no mencionar las dos Sátiras del suicidio romántico que con tanta viveza plasmó en el lienzo Leonardo Alenza en 1839. El suicida, sea por amor, desasosiego, o por el quiebre insalvable de su honor, deviene protagonista, capaz de concentrar en su figura todas aquellas pasiones que modelan y motivan la estética del siglo XIX. Se trata de una visión común, compartida desde una sensibilidad aparentemente nueva. Doré probablemente sea un claro deudor de esta estética, pero eso no implica la falta de respeto y de fidelidad al texto original, tal y como se repitió en los círculos italianos. Al contrario, la conjunción entre la sensibilidad romántica y el conocimiento del texto derivó en una aproximación mucho más fidedigna de la selva, otorgando el lugar merecido, artísticamente hablando, a su verdadero protagonista: Pier della Vigna.

Lo que son Paolo y Francesca al canto IV, Bertran de Born al XXVIII o Ugolino al XXXIII, lo es Pier della Vigna al XIII. El alma desamparada que conmueve a Dante, aquel que vertebra el desarrollo del canto, el catalizador de las pasiones de aquel escenario macabro. No obstante, las representaciones artísticas de la Comedia, desde sus inicios hasta finales de siglo XVIII, jamás otorgaron al personaje un protagonismo claro, sea por fidelidad literal al canto, comodidad en el caso de las miniaturas de los códices o bien por el rechazo que aparentemente suscitaba la figura del suicida. Della Vigna, probablemente, se trate del mayor olvidado de todas las ilustraciones dantescas de la historia del arte. Si bien en algunas imágenes se lo identifica mediante una referencia textual, en la mayoría es un elemento más del paisaje y la atención recae, como es usual, sobre Dante y Virgilio. Más allá de ellos, la única referencia «humana», en cuanto a ser que siente, sufre y actúa como tal, se encuentra en la presencia de Lano di Siena y Jacopo de Sant'Andrea.

I3. Es conocida la leyenda (urbana, apostillaríamos hoy) construida alrededor de la novela de Goethe, según la cual un considerable número de lectores jóvenes quisieron emular el suicidio del protagonista. Esto pone de relieve la consideración popular del suicida, que no distaría en exceso de ciertas modas o comportamientos diseminados en Occidente a finales del siglo XX y principios del XXI en algunas tribus urbanas.

I4. Véase el caso de Nathanael en El hombre de arena (1817). 
Flaxman, cuyo trabajo llegó a ser menospreciado por algunos críticos favorables y contemporáneos de Doré (Montégut 186I: 443-45), fue el primer artista en representar al personaje. Lo hizo mostrando a Dante tirando de una de sus ramas con un gesto casi cómico, con una apariencia que llega a recordar a la del superhéroe de nuestros días, descubriendo sus ropas ajustadísimas bajo la capa; con fuerza y una posterior expresión de desconcierto, el poeta logra arrancar esa rama, de la que no se ve brotar sangre, pero sí se intuye el dolor en el rostro apenas esbozado del condenado. Probablemente se trate del primer intento de humanización de un personaje que, hasta entonces, había carecido de una especial atención; la literalidad de las representaciones lo había condenado a ser un árbol más, reconocible únicamente por las inscripciones añadidas a posteriori. La viveza, el drama y la expresividad del condenado y de su discurso se veían perdidas en pos de esa fidelidad al texto que, irónicamente, menguaba de manera importante su impacto y su contenido emocional y expresivo. Dada la ambigüedad de la representación de Blake, no parece ser un disparate considerar al Pier della Vigna de Flaxman el precedente más inmediato del que imaginaría después Doré. ¿Influencia directa o, por el contrario, una sintomática visión fruto de la sensibilidad de su propia época? Es difícil, sino imposible, saberlo con exactitud. Lo cierto es que, en I86I, el francés brindaría la que sería probablemente la imagen más contundente de aquel personaje que, por tanto tiempo y en el arte, había caído en el olvido.

Dante y Virgilio, siempre según Doré, acceden al bosque de los suicidas siendo meros figurantes de aquello que se muestra al espectador. Sus siluetas se recortan en el fondo, donde yacen las aguas del Flegetonte, los rostros casi imperceptibles, parcialmente ocultos en las sombras; lo que debe atraer la atención no son ellos, sino el pandemonio al que precisamente se dirigen. Las harpías chillan (emettono lamenti sugli strani alberi), ${ }^{\mathrm{IS}}$ los árboles lloran y lamentan su desventura. No debería ser un entorno amable, ni mucho menos, siendo capaz de hacer temblar el pulso de un Dante que no se ha acostumbrado aún (ni lo hará a lo largo de su avance) a las abominaciones del Infierno; esto Doré lo comprende con acierto, volviendo a demostrar en este caso una tendencia singular, que no se basa en otra cosa que en otorgar una especial atención a quienes concentran la narrativa de cada canto. Sirviéndose de su dominio del claroscuro, ilumina el cuerpo transformado de Pier della Vigna de un modo cercano a lo teatral, como encontrándose bajo un potente foco de luz. El mismo efecto (Regnoni-Macera Pinsky 1987: 274-275) se observa en su Caifás (fig. 13), Francesca o en su Aracne, ésta ya en el Purgatorio. Para Doré, Dante no debe ser siempre, necesariamente, el protagonista de todas 
las escenas. Precisamente, porque la carga dramática en el poema recae en el antiguo notario de Federico II.

El interés por el condenado parece ir más allá de la necesidad de cumplir con el discurso narrativo del texto. Si en la escena en que Dante arranca la rama de donde brotará la sangre es incuestionable que quien tiene enfrente no es otro que el autor del Epistolario latino, en las dos ilustraciones restantes que abordan también los acontecimientos del canto se entrevén dos figuras que bien pueden tratarse del mismo personaje. En la primera, dicha figura aparece abajo, justo a los pies del condenado en actitud avergonzada; en la tercera, perteneciente a la huida de los derrochadores, una versión similar se encuentra en el margen inferior derecho. Es difícil, si no imposible, establecer si el personaje se trata de Pier della Vigna. Por un lado, su ubicación a duras penas encaja en las tres ilustraciones: los suicidas a su alrededor se encuentran en posturas distintas; por el otro, ni siquiera esa misma figura aparece reproducida con exactitud. Si bien yace con la espalda hacia inclinada hacia atrás, una de las rodillas alzadas y la cabeza colgando entre sus hombros, detalles como las ramas en que se transforman sus manos son sensiblemente distintos entre unas y otras. No obstante, atendiendo a la repetida presencia de personajes recurrentes en segundo plano (Mahoma, Bertran de Born) podría tratarse de una hipótesis válida.

Sea como fuere, la vivacidad y el significado con que esto impregna su narrativa es difícilmente cuestionable, y hace patente el interés por ensalzar los rasgos más dramáticos del poema. Por eso, no desentonan las carencias lógicas en escena. Parecería obvio que Dante apenas se va a sorprender cuando vea la sangre brotar de la rama rota, puesto que el antropomorfismo y los aullidos de dolor no dejarían lugar a dudas, pero aun así logra confeccionar una escena cautivadora. El cuerpo de Pier della Vigna se encuentra en una postura que expresa sin necesidad de palabras el pathos con que casi derrumbará a Dante, viéndose obligado a pedir a Virgilio que intervenga en su nombre:

Ond' io a lui: «Domandal tu ancora

di quel che credi ch'a me satisfaccia;

ch'i' non potrei, tanta pietà m'accora"

(If. XIII, 82-84)

En efecto, las diferencias estéticas y compositivas entre la escena original y la de Doré son significativas, claras a simple vista. Pero aun así, el potencial expresado es similar y fácilmente comparable. La clave de la representación más acertada del canto es el haber dado forma humana al condenado, del mismo modo que la pequeñez de Dante y Virgilio en algunas escenas es determinante a la hora de traducir las proporciones sobrehumanas del Infierno e ilustrar el componente de lo sublime presente en los versos. 
El antropomorfismo permite dotar de empatía lo inerte y lo abstracto. El árbol con rasgos humanos se hace cercano, del mismo modo que el minotauro parece un ser menos monstruoso que una arpía o que una quimera. Podría argumentarse hasta qué punto esto contradice la propuesta dantesca, que se decanta de manera clara por lo anónimo y lo genérico en detrimento de la individualización, pero es más que probable que tales decisiones, en el ámbito artístico, obedezcan a una razón y a una exigencia narrativas. Sea como fuere, son pocas las imágenes anteriores que ponen el foco sobre el diálogo entre Dante y Della Vigna. En caso de darse, se percibe vacía, carente del impacto contenido en los versos y en las palabras con que el Poeta expresa su particular desconsuelo, mucho menos en el caso del desconsolado discurso con que el condenado rememora su fatídico final. La tensión y el drama ya los advirtieron D'Ovidio y De Sanctis (De Sanctis I866: 409-26), entre otros, y semejante lectura manifiesta un nuevo acercamiento a la Comedia que, en el arte, Doré logró tanto introducir como ilustrar. Aquel Infierno como reflejo del mundo real que había descrito Schopenhauer (Schopenhauer I819: 428) en su intento de dar una explicación a la atracción que ejerce el Infierno por encima del resto de las partes, se entiende en unas imágenes que parecen querer poner de relieve el sufrimiento no solo carnal sino especialmente el emocional de los condenados. Una Francesca dolida, con la herida aún sangrante entre sus pechos, sostenida por un Paolo desconsolado que oculta su rostro tras la palma de la mano, un Ugolino que vemos sufrir un claro proceso de degeneración a lo largo de su encierro, y un Pier della Vigna (así como sus compañeros de condena) cuyas ramas y raíces retorcidas evocan el sufrimiento de quien, buscando desprenderse de su vida y de su cuerpo, no ha obtenido más que lo mismo y en la peor de las circunstancias. Doré parece descubrirse como el nexo entre la percepción literaria de la Comedia y su recepción artística. Desde luego, las evidencias hacen que pueda considerarse el primero de todos los artistas que aborda determinadas escenas que sus compañeros de profesión bien procurarían evitar ante la amenaza de los guardianes del bon gout..$^{16}$

I6. El crítico E. Vinet escribió, una vez publicadas las ilustraciones del Infierno y en referencia a la escena de Ugolino devorando a Ruggieri degli Ubaldini, que el trabajo de Doré contradecía de manera sensible los postulados de Lessing, quien en su Laoconte afirmaba que no todas las escenas de la literatura eran susceptibles de ser representadas por aquello que describían: «¿Es permisible rebajar el arte al nivel del canibalismo? ¿Puede el pintor mostrarnos a Ugolino desgarrando con sus dientes afilados el cráneo sangriento de su enemigo? ¿Qué más da si esta escena horrible nos la ofrece Dante? No todo lo de este gran poeta debería reproducirse en el arte. Lessing, en su bello análisis crítico titulado Laoconte, [...] bien demostró que de quince a veinte escenas de Homero, hay quizás diez que no deberían ser reproducidas en pintura, a propósito de los límites establecidos entre la poesía y el arte por el buen gusto, o lo que es lo mismo, por la parte más delicada del sentido común.» (Audeh 20I0: I43). 


\section{¿LUCIDEZ O FANTASÍA NEURÓTICA? CONSIDERACIONES FINALES}

Quizá la tarea del ilustrador no sea otra que transformar en forma de imagen las palabras y el efecto que éstas crean, más que limitarse al estricto patrón de unos versos de manera literal. Es en estos momentos en que la imagen debe suplir al texto y no subyugarse a él cuando Doré brilla como ilustrador y donde los esfuerzos anteriores se ven afectados por una tibieza considerable. Hoy, más que nunca, se comprende que una traslación literal de texto a imagen suele resultar en algo, de pronto, descafeinado. Sucede en el mundo del cine, cuando en adaptaciones cinematográficas de obras literarias las escenas más potentes en la imaginación del lector devienen en anodinas y planas en el celuloide. Sin embargo, las adaptaciones verdaderamente acertadas suelen ser siempre aquellas que logran sintetizar el alma de una obra en un contenido que quizá, visualmente, diste de lo descrito en el texto. Es esta manera de comprender la ilustración lo que da valor a la obra de Doré.

Como ya se ha afirmado anteriormente, desde el momento de su publicación el Infierno ilustrado por Gustave Doré fue recibido con opiniones opuestas. Expuestas las posiciones más diferenciadas y analizado su discurso, es evidente que la recelosa valoración de los críticos más acérrimos se sustenta sobre una noción por lo menos comprensible, pero no por ello menos inocente. Si bien es cierto que a simple vista pueden encontrarse rasgos muy particulares que parecen tomarse la Comedia como tan solo un trampolín hacia su propio y singular imaginario, una lectura comparativa y atenta de la fuente original y las imágenes acaba desvelando una comprensión quizá mayor de la de quienes ilustraron el poema con, aparentemente, mayor fidelidad. La popularidad de Doré y su marcadísimo estilo en su labor ilustrativa probablemente definieron el devenir de esta apreciación como artista de segunda fila, no por su técnica (aunque Volkmann incide en dar protagonismo más a los grabadores que al mismo Doré) ${ }^{17}$ sino por algo que puede llegar a ser tan abstracto como es su visión artística o poética.

Esto no significa, no obstante, que su tratamiento de las imágenes dantescas sea menor o deficiente, siendo precisamente la escena del canto XIII uno de los más claros ejemplos de su lucidez, que no tiene por qué estar reñida con una imaginación desbordante y un acercamiento muy personal a una situación y a unos personajes universales. Se muestra, como con Scaramuzza o Flaxman,

17. En efecto, en su Infierno Doré no ejerció de grabador sino de ilustrador. El éxito del resultado se reparte, por lo tanto, entre el alsaciano y los grabadores de los distintos talleres con que colaboró (Pisan, Pannemaker, Trichon et Guillaume, entre otros). Aun así, es cuestionable que esto sirva como justificante a la advertencia de Volkmann, pues es obvio que sin la idea original, surgida de la mente y la mano de Doré, nada de esto se hubiese hecho realidad. Sería interesante, de cara a estudios más minuciosos sobre el desarrollo de estos grabados, conocer los dibujos originales de los que, en caso de no haber sido destruidos, no se conoce la localización. 
la habilidad de captar el significado poético de unos versos cuya traslación literal al mundo de la imagen se ve afectada por una anticlimática falta de rotundidad; no por fallo de Dante, sino por tratarse de dos lenguajes distintos que en modo alguno deberían considerarse intercambiables. Es evidente que la crítica contemporánea que cargó contra Doré, como afirma Cole, lo hizo sin poner excesiva atención en una lectura de las imágenes en comparación con el texto más allá de un vistazo meramente formalista. Puede concluirse que, en la época, la falta de entendimiento entre arte y pensamiento no fue ni mucho menos unidireccional (los productos filosófico-artísticos fruto del estudio de la Comedia, en muchos casos, son antitéticos).

La visión de Doré del canto XIII, al contrario de lo que se afirmó en su momento, no parece ser exclusiva de una mente fantasiosa sino que, como se ha podido ver, obedece a diversos criterios de carácter general propios de su época. ${ }^{18}$ Por un lado, a una lectura de la Divina Comedia marcada por las ideas estéticas de su tiempo; por otro, a la aceptación popular del suicida no como un apestado sino como un personaje impregnado de dramatismo y heroicidad; por último, a lo que parece ser una influencia clara de representaciones anteriores del canto (Flaxman, Blake). Salvo la imagen de los condenados con forma de árboles antropomorfos y expresivos no se percibe, ni mucho menos, una rotura radical con ilustraciones precedentes: el escenario seco es el mismo, así como la imagen de Dante arrancando la rama de donde brotarán sangre y palabras. Asimismo, no se trata de una apuesta tan original ni tan fantasiosa; quizá esto último sea lo que suscite un debate más polémico, intrincado y de difícil resolución. Entran en conflicto las maneras de entender el arte de la ilustración, y en función de los criterios la manera de abordar la Comedia según Doré (así como el resto de sus grandes obras de la literatura ilustradas) puede percibirse como fenomenal, correcta o desastrosa. No cabe duda de que la razón principal por que los grabados del francés fueron criticados por ciertos sectores surge de una manera particular de entender el ejercicio de ilustrar, que ponía por delante la literalidad del texto (sin aceptar, según parece, interpretaciones que subyazcan en lo aparente) y, al mismo tiempo, criterios que guardaban más relación con lo moral que con lo puramente artístico.

El canto XIII según Gustave Doré, al contrario de lo pretendido por Volkmann, se descubre precisamente como uno de los mejores ejemplos de lucidez del artista, de una manera clarividente de entender la ilustración y por ende, en este caso, la Comedia. Podrían ponerse en cuestión otras resoluciones, como

I8. Es acertada, desde luego, su vinculación con la noción hegeliana de lo «arabesco», entendido como una vegetación desatada en que se intuyen al mismo tiempo formas humanas y animales, como si éstas formaran un todo con dichas plantas, en una simbiosis que, por supuesto, tiene su eco en las metamorfosis vegetales de origen clásico que observamos en Ovidio o en Virgilio (Kayser 20I0: 17I-I73). 
la vaguedad de la metamorfosis de Agnello o la desabrida representación de Lucifer, que sí rebajan considerablemente el nivel de la interpretación con aproximaciones superficiales o que se ven afectadas de manera negativa por la narrativa o la sensibilidad literaria de la época. No obstante, su bosque de los suicidas es el punto culminante de un proceso de reinterpretación de una imagen que no parte de una invención desconsiderada sino de la avenencia (consciente o inconsciente) con una visión moderna que a la vez encaja con la sensibilidad que subyace en los versos originales: Pier della Vigna, un repudiado por la sociedad de su época convertido en un personaje central merecedor de compasión, la tortura de las almas condenadas como recurso dramático y a la vez como herramienta para configurar la geografía infernal, un inframundo terrible pero esencialmente humano que, tal y como afirmase Schopenhauer mucho antes de que estos grabados viesen la luz, no es más que un reflejo de nuestro mundo real. Quizá la aceptación popular de las imágenes de Doré y su posterior influencia no hacen sino confirmarlo. 


\section{ANEXo DE IMÁGENES}

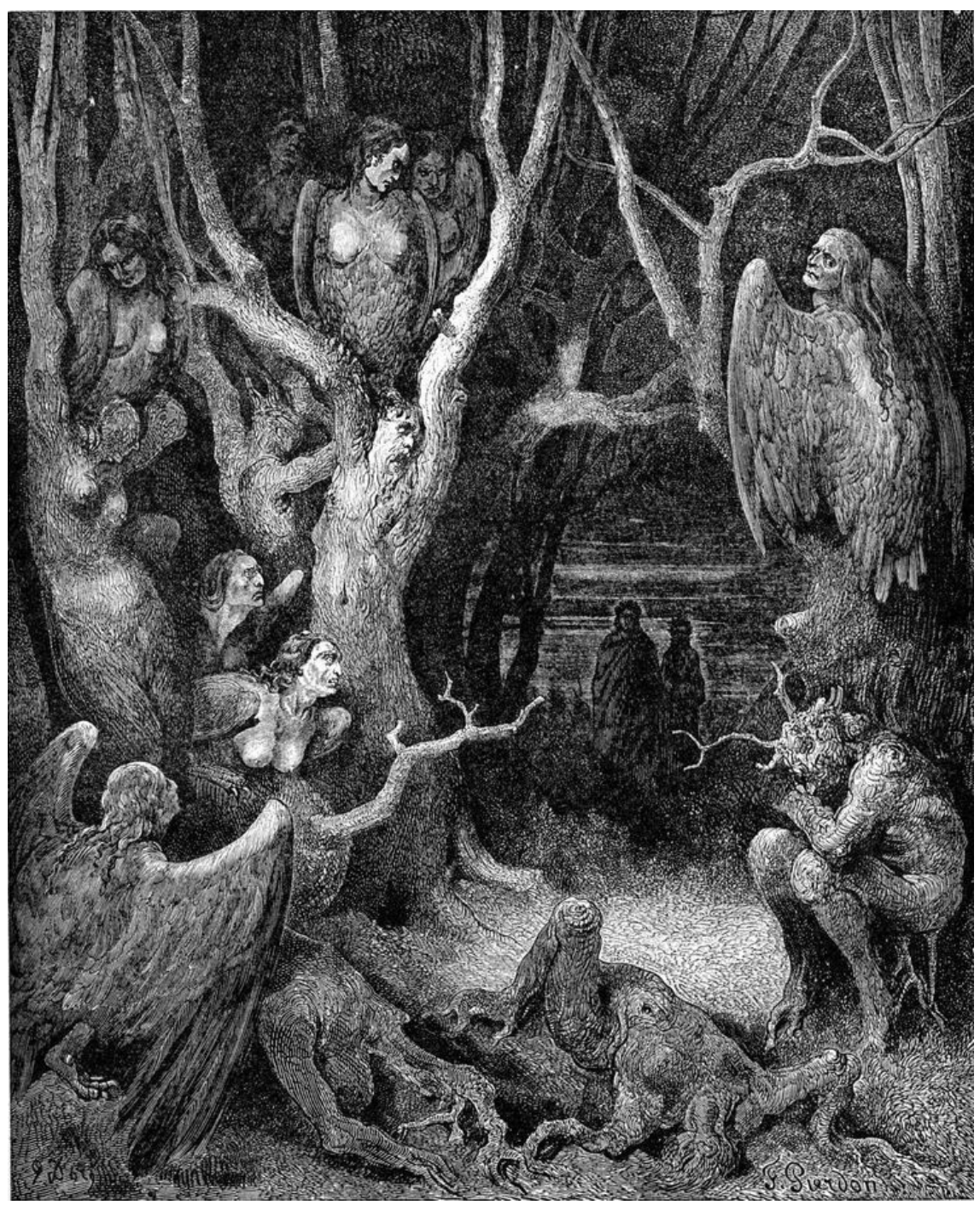

Fig. I. Gustave Doré, Bosque de las arpías, grabado en madera, en L'Enfer de Dante Alighieri, avec les dessins de Gustave Doré, 1861, París, Bibliothèque national de France. 

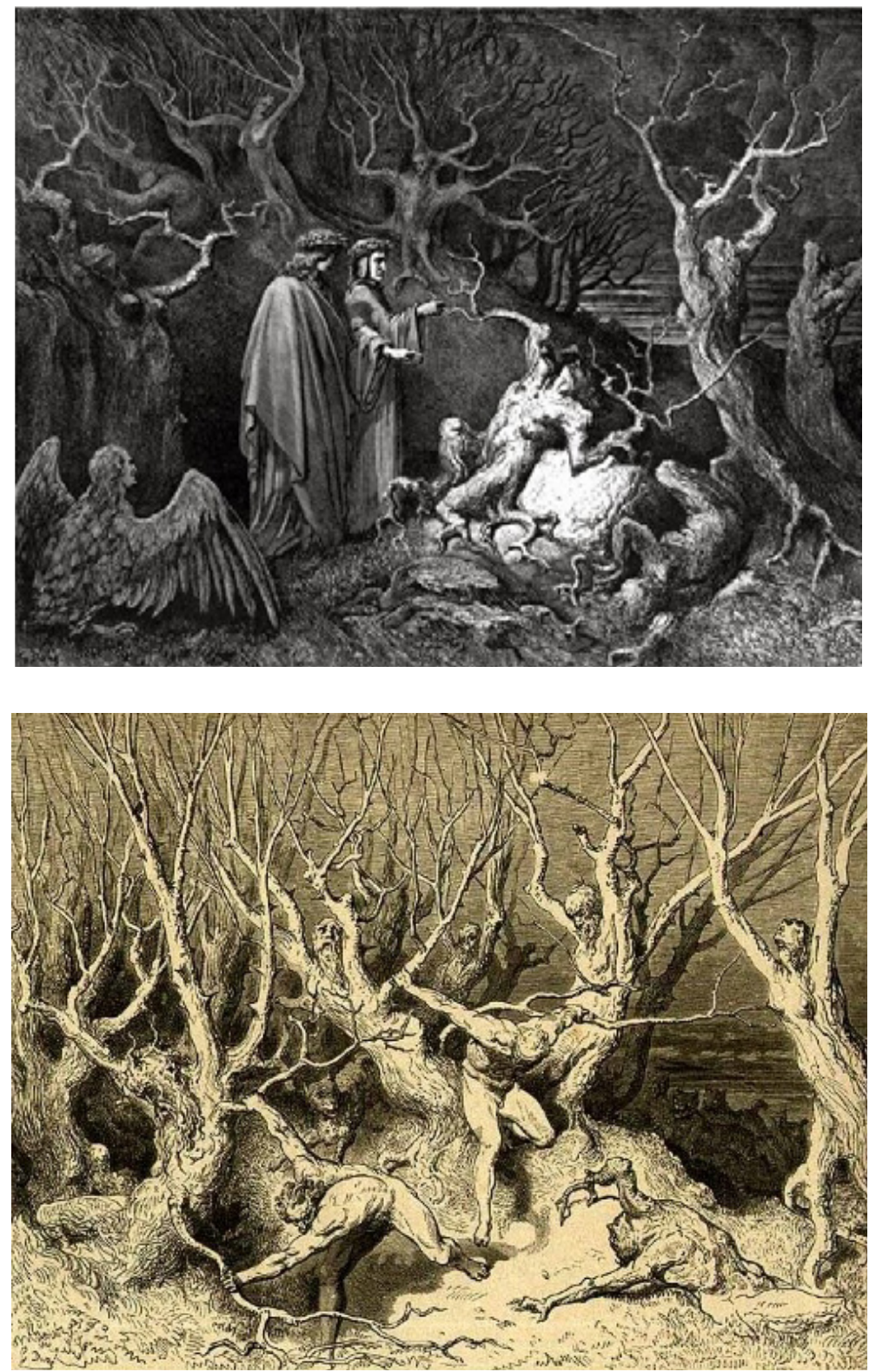

Fig. 2. Gustave Doré, Los suicidas, grabado en madera, en L'Enfer de Dante Alighieri, avec les dessins de Gustave Doré, I86I, París, Bibliothèque national de France.

Fig. 3. Gustave Doré, Los suicidas, grabado en madera, en L'Enfer de Dante Alighieri, avec les dessins de Gustave Doré, I86I, París, Bibliothèque national de France. 


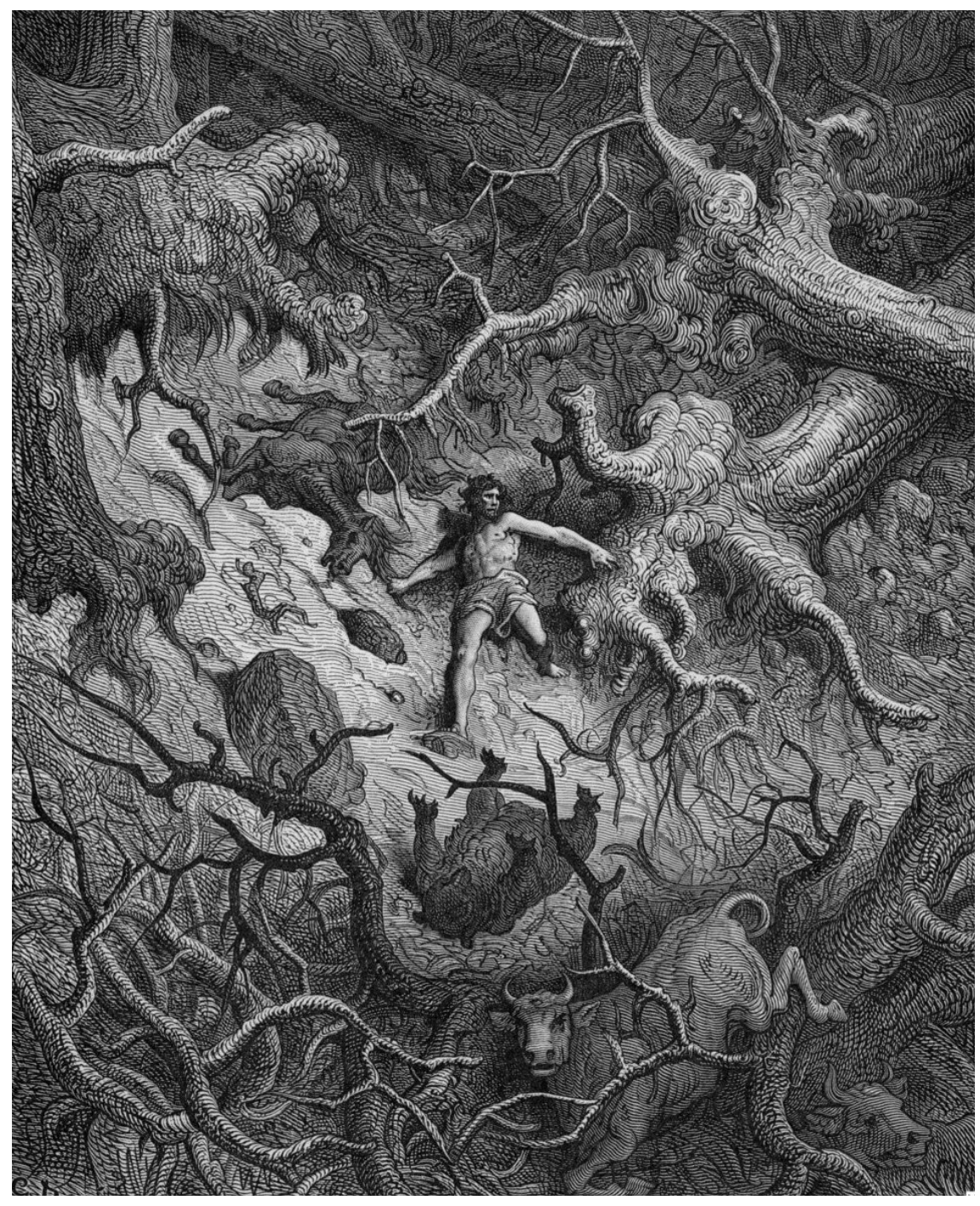

Fig. 4. Gustave Doré, La locura de Orlando, grabado en madera, en Orlando furioso di Ludovico Ariosto illustrato da Gustavo Doré, 1880, París, Bibliothèque national de France. 

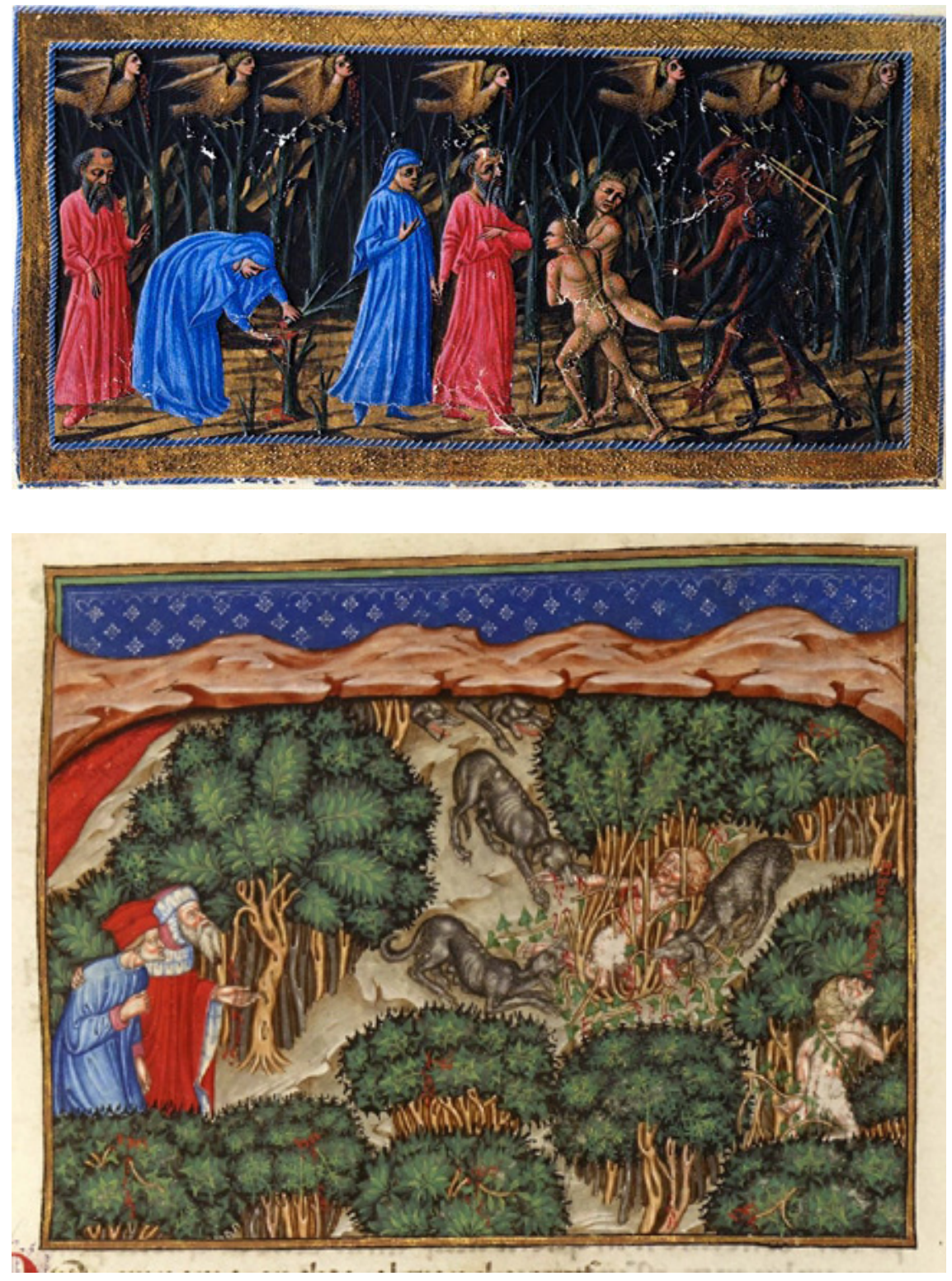

Fig. 5. Priamo della Quercia, Bosque de los suicidas y derrochadores, miniatura, I444-52, Códice Yates Thompson 36, Londres, British Library.

Fig. 6. Anónimo, Bosque de los suicidas, miniatura, segunda mitad del s. XV, Ms Italien 20I7, Paris, Bibliothèque national de France. 

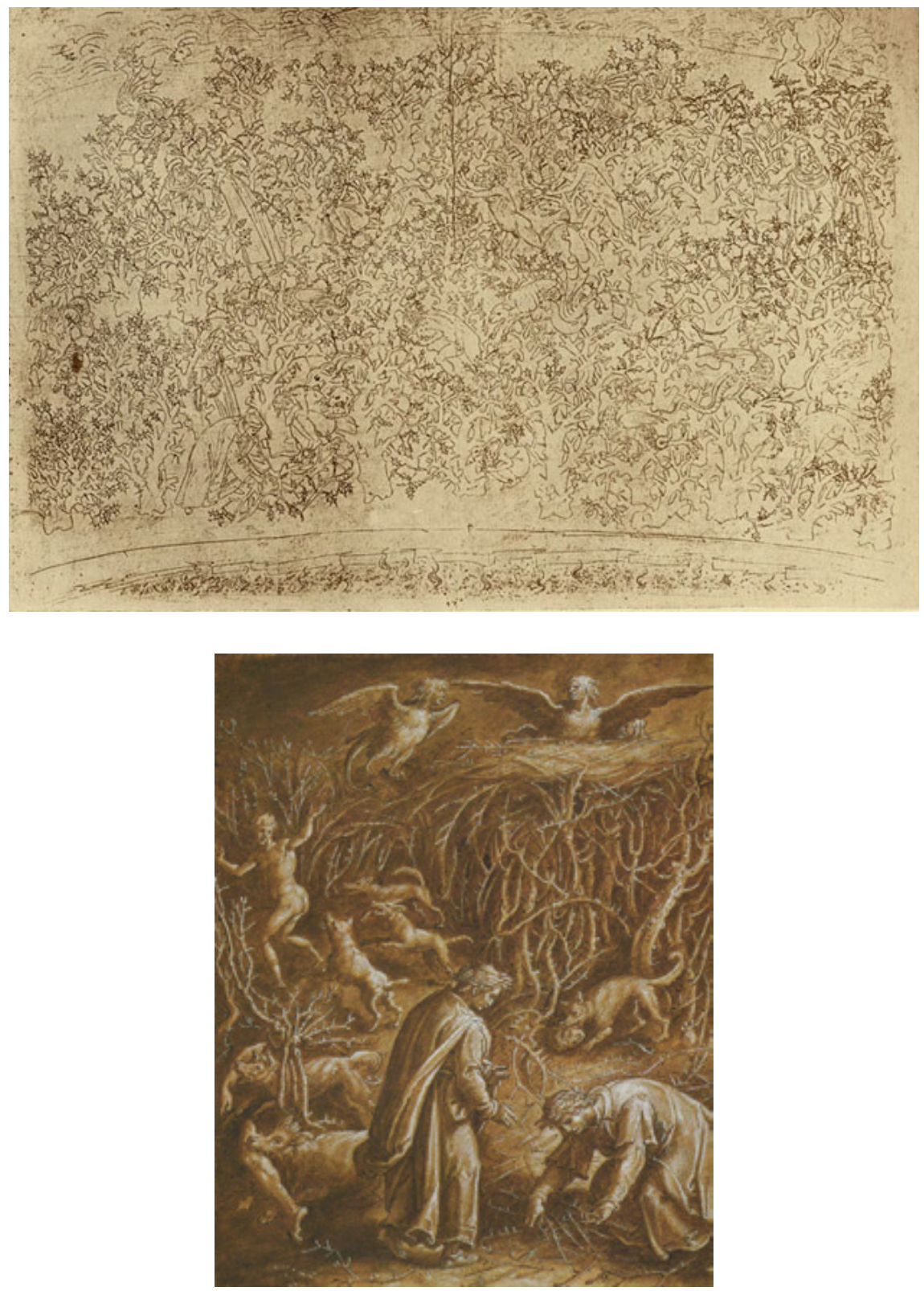

Fig. 7. Sandro Botticelli, Los violentos contra si mismos, tinta sobre pergamino, h. I480-I495, Roma, Biblioteca Vaticana.

Fig. 8. Jaan van der Straet (Giovanni Stradano), Bosque de los suicidas, 1597, Florencia, Biblioteca Laurenziana. 


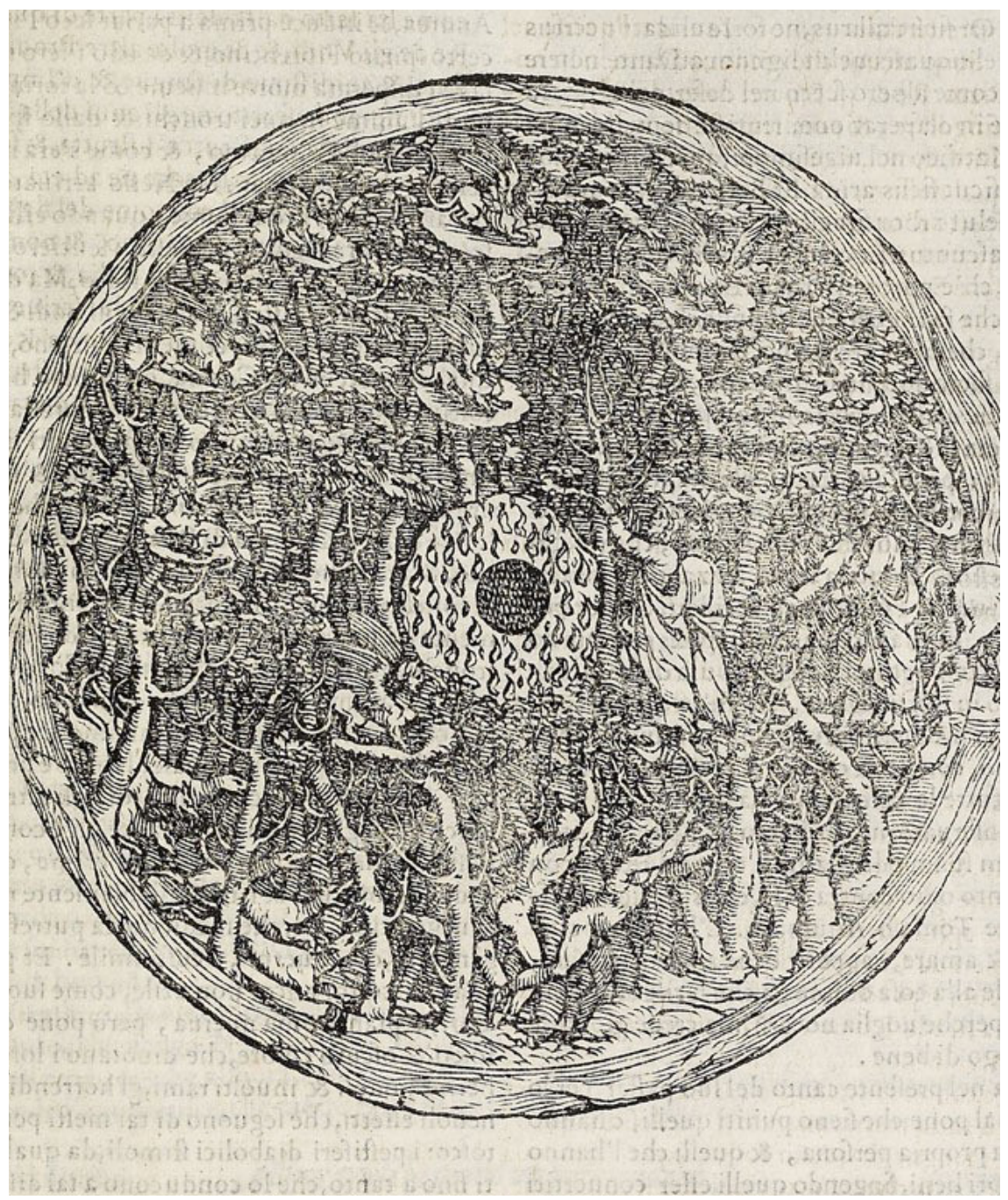

Fig. 9. Giovanni Britto, Dante y Virgilio en el bosque de los suicidas, xilografía, I544, La Spezia, Biblioteca Ubaldo Mazzini. 

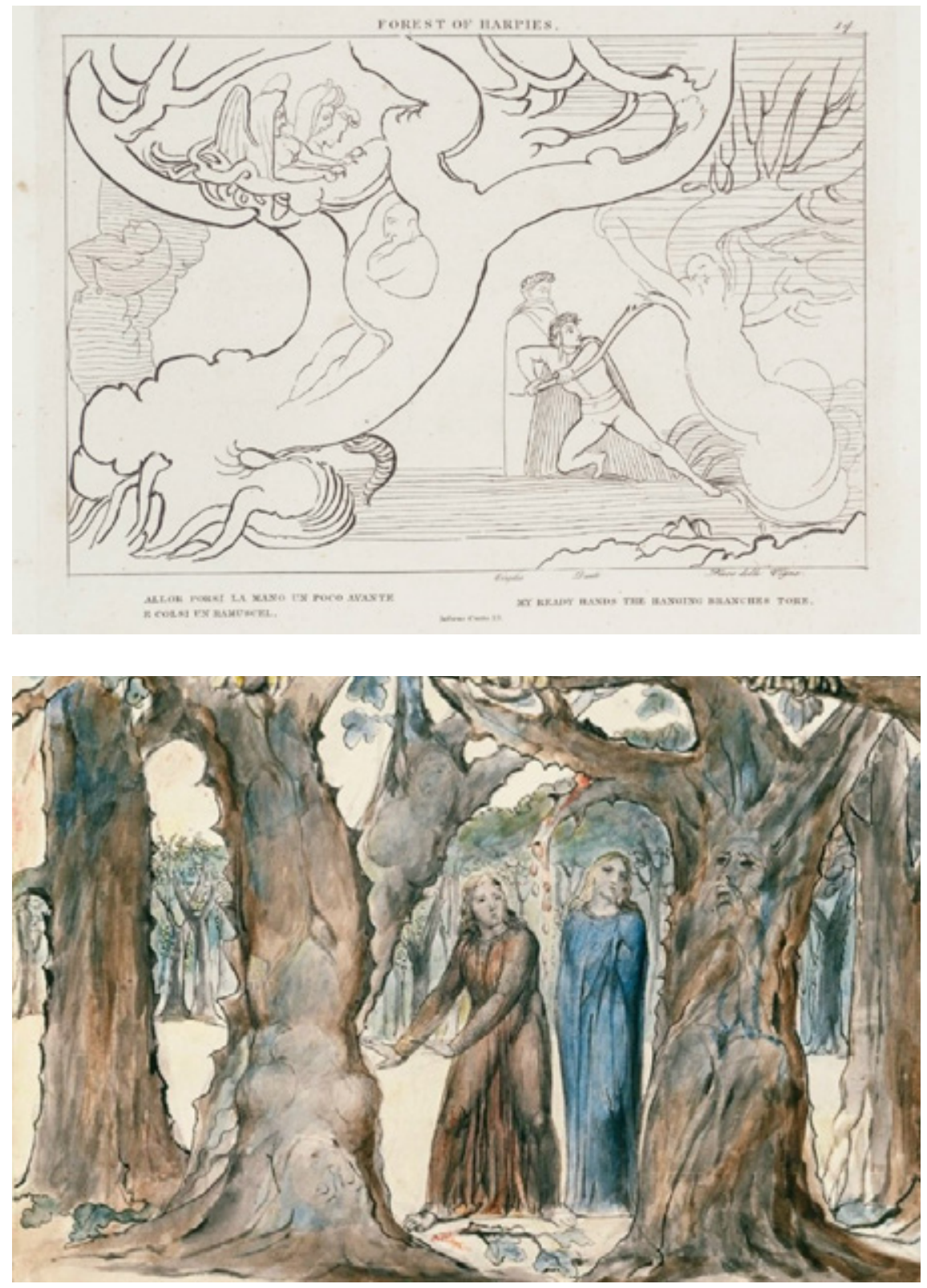

Fig. Io. John Flaxman, Bosque de las arpías, aguafuerte, reproducción de 1807 a partir del original de 1793, Londres, Tate Modern.

Fig. II. William Blake, El bosque de los suicidas: las arpias y los suicidas, grafito, tinta y acuarela sobre papel, I824-27, Londres, Tate Modern. 


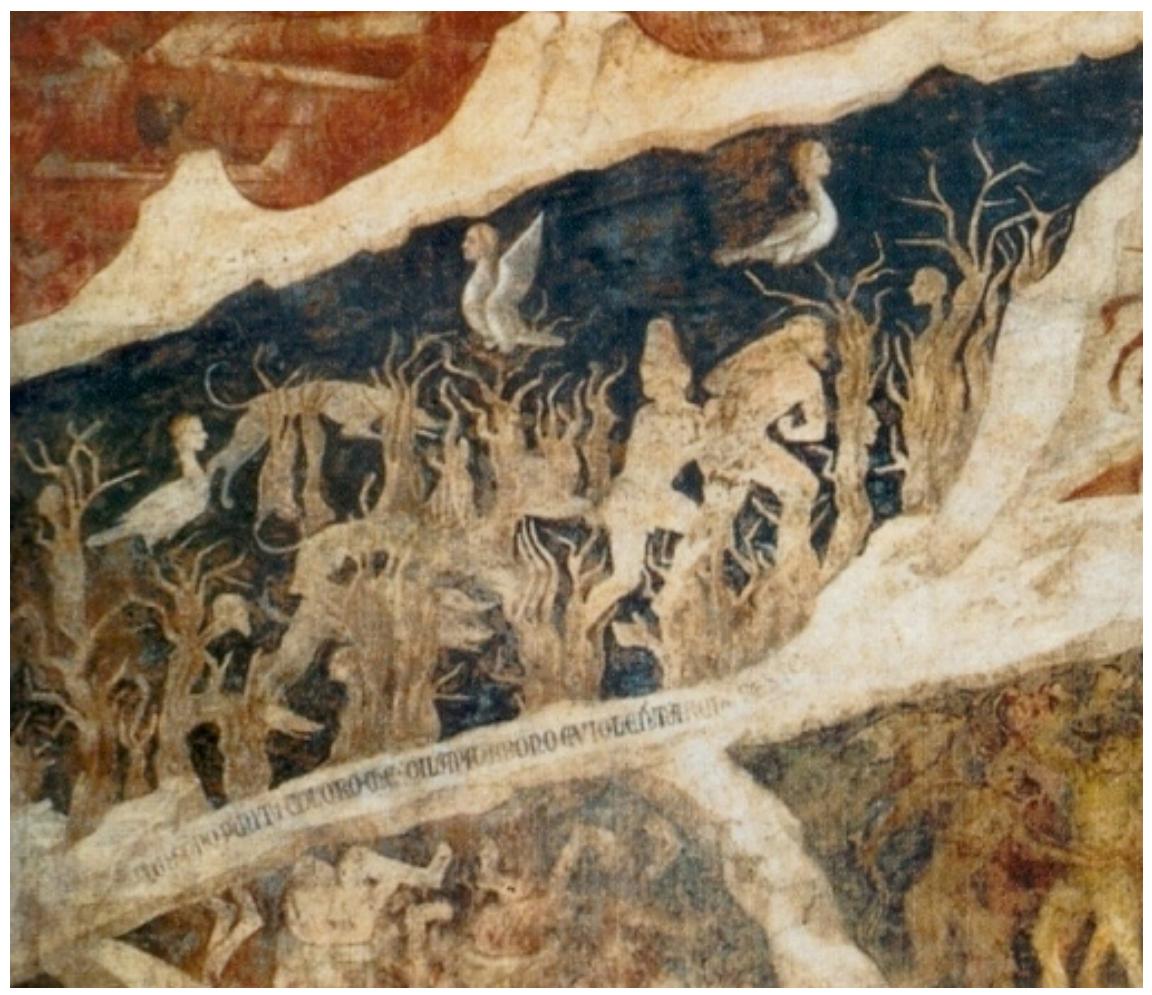

Fig. I2. Nardo di Cione, Inferno (detalle de la Capilla Strozzi), fresco, I357, Florencia, Santa Maria Novella. 


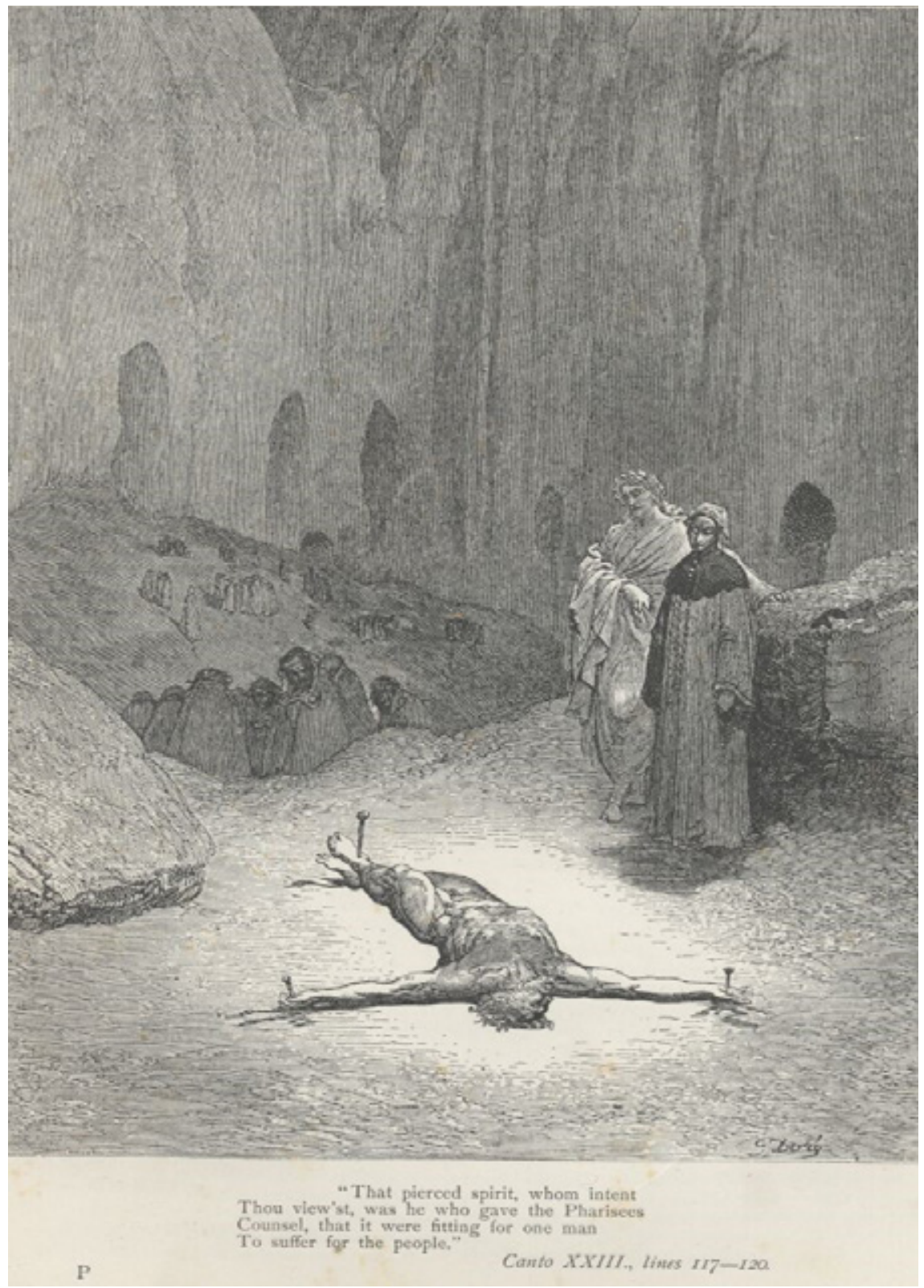

Fig. I3. Gustave Doré. Los hipócritas-Fariseo crucificado, grabado en madera, en L'Enfer de Dante Alighieri, avec les dessins de Gustave Doré, I86I, París, Bibliothèque national de France. 


\section{BiBLIOGRAFÍA}

Arqués, R., "Sangre y palabras", El libro y la carne (hermenéutica del libro), Universidad de Sevilla, I998.

Audeh, A., "Gustave Dorés Illustration for Dante's Divine Comedy: Innovation, Influence and Reception", Studies on Medievalism XVIII, 2010.

-, "Dante's Ugolino and the School of Jacques-Louis David: English Art and Innovation", Nineteenth-Century Contexts, 2013.

Bettelheim, B., Psicoanálisis de los cuentos de hadas, Crítica, Barcelona.

Blanchard Jerrold, W., Life of Gustave Doré, Londres, I892.

Carlier, S., "Gustave Doré, Dante et Virgile dans l'Enfer de Dante", L'Enfer Doré: Dante et Virgile dans le neuvième cercle de l'enfer, FAGE, Lyon, 2004, p. 3I.

Celli, A., "Perché mi scerpi? Il canto di Pier delle Vigne tra Hegel e De Sanctis", Conferencia en la Università di Lugano, I9 de noviembre de 2008.

Cole, W., "Literal art? A new look at Dorés illustrations for Dante's Inferno", Word \& Image. A Journal of Verbal/Visual Enquiry, X, I994.

De Sanctis, F., "Pier delle Vigne", Saggi critici, Cav. Antonio Morano, Nápoles, I888.

Doré, G., The Doré Illustrations for Dante’s Divine Comedy, Dover Publications, Nueva York, 1976.

G. Cortés, J.M., Orden y caos. Un estudio cultural sobre lo monstruoso en el arte, Anagrama, Barcelona, 1997.

Irwin D., "Flaxman: Italian Journals and Correspondence", Burl. Mag, C.I., I959.

Kayser, W., Lo grotesco. Su realización en literatura y pintura, La balsa de la medusa, Madrid, 2OIO.

Larchey, L., "Paru pour le Jour de l'An”, Le Bibliofile Français (diciembre de I869).

Leopardi, G., Zibaldone di pensieri, Einaudi,

Regnoni-Macera Pinsky, C., "Lillustrazione della Divina Commedia di Gustave Doré e la sua relazione con quella di Sandro Botticelli e William Blake", Letteratura italiana e arti figurative I, Florencia, 1987.

Renonciat, A., La vie et l'œuvre de Gustave Doré, Bibliothèque des Arts, Paris, 1983.

Schopenhauer, A., Il mondo come volontà e rappresentazione, Laterza, Bari, 1979.

Sgarbi, V., Scaramuzza,

Urraro, R., "Lettura testuale del XIII canto dell'Inferno dantesco", 2007.

Volkmann, L., Iconografia Dantesca, Breitkopf \& Härtel, Leipzig, I897. 